\title{
ÚLOHA NATO V BEZPEČNOSTNÍ POLITICE USA
}

\section{THE ROLE OF NATO IN THE U.S. SECURITY POLICY}

\author{
Vit $\check{S}^{T} \mathrm{TIF}{ }^{*}$
}

\begin{abstract}
Abstrakt
Konec studené války znamenal přesun úlohy Severoatlantické smlouvy - NATO - od společenství založeného na obranu zúčastnivších se států na seskupení zvládající širší úkoly, zvláště mise mimo vlastní území na Balkáně a Středním východě. USA je vždy považovaly za hlavního spojence v Evropě, po studené válce se však jeho úloha v bezpečnostní politice USA sníżila. Po mezinárodních misích na Balkáně v 90. letech uvažovala část predstavitelu jejich diplomacie, že většina evropské části NATO neznamená pro USA spolehlivého spojence. Vývoj po 11. zárí 2001 ukázal, že se ani tak silný stát jako USA bez spojenců neobejde, chce-li vést úspěšnou zahraniční politiku.
\end{abstract}

\begin{abstract}
The end of the Cold War meant transformation of the role of NATO from community raised for defense of participating member states to a group which manages wider tasks, particularly missions beyond its own area in the Balkans and Middle East. The USA have always considered NATO as its most important European ally, however, after the Cold War its role in the security policy of the USA has lost some of its importance. After international missions in the Balkans in the 90s some of the USA diplomats have begun to think that most of European part of NATO did not mean a reliable ally for the USA. The development after $11^{\text {th }}$ September 2001 has shown that even such a strong state like the USA cannot act without allies, if it wants to lead a successful foreign policy.
\end{abstract}

\section{Klíčová slova}

Bezpečnostní společenství, operace na budování míru, NATO, obranné společenství, USA.

\section{Keywords}

Security community, peace-building missions, NATO, defense community, USA.

$* * *$

\section{ÚVoD}

NATO vzniklo začátkem studené války jako obranné společenství severoamerických a západoevropských států proti bloku států ve střední a východní Evropě v čele se SSSR a tuto podobu si zachovalo do konce dvoupólového uspořádání světa v závěru 80. let. Zahrnovalo více států než výše uvedený základ, prričemž část z nich představovaly jihoevropské státy. Zvláštní postavení náleží Turecku, jedinému státu NATO s většinou muslimského obyvatelstva.

Úloha NATO z období studené války ve smyslu obrany proti SSSR a jeho spojencům skončila. V souvislosti s tím se rozhodovalo o zdůvodnění jeho následujícího trvání. Představy o stavu bez přítomnosti zdrojů ohrožení, at’ přímo pro jeho státy, nebo častěji v jejich užším a širším okolí, netrvaly dlouho, protože se řada států NATO, hlavně těch nejvýznamnějších, začátkem 90 . let zúčastnila několika střetů, i když zprvu nešlo o zásahy NATO, ale jiných spojenectví.

\footnotetext{
*E-mail: vitstaif@c-box.cz.
} 
Nejsilnější stát v NATO, USA, se těsně po skončení studené války nacházel na rozcestí, co se týče směru zahraniční politiky. U části veřejného mínění i politických špiček rostlo přesvědčení, že vliv v zahraničí je zapotřebí zúžit a spíše řešit vnitřní záležitosti USA. To většinou neznamenalo volání po uzavírání se do sebe, ale spíše chování v mezích více-méně, a v 90. letech tyto názory ztrácely vliv.

Jiná část architektů zahraniční politiky USA chtěla jejich zahraniční vliv zesílit a část z nich sledovala dosažení naprosté hegemonie USA, vůbec poprvé. Nezávisle na jejich založení se zachovalo, že USA ve vztahu k evropským státům využívaly i v 90. letech na prvním místě NATO. Ani za studené války se státy v NATO nechovaly vždy jednotně a to přetrvalo i po jejím ukončení. Vývoj mezinárodních vztahů vícekrát zaznamenal spolupráci mezi nejvýznamnějším státem tohoto společenství a jeho dalšími členy i jejich neshody, které začátkem 21. století přerostly do výrazného zhoršení v jejich vztazích, i když se v posledních dvou letech zdá, že se tento zjev neprojevuje tak silně jako po útocích proti USA z 11. září 2001 a začátkem války proti Iráku na jar̆e 2003.

Tato práce se věnuje povaze vztahu USA k NATO po studené válce. Soustřed’uje se na využití NATO při šírení jejich vlivu v Evropě a mimo její území a na změnu jeho poslání. Zvláštní pozornost zasluhují mise NATO usilující o zavedení a uchovávání míru a prosazení ustálených poměrů v prostředí postiženém střety nebo vyhroceným politickým stavem. V 90. letech šlo hlavně o bývalou Jugoslávii, po 11. záŕí 2001 o Afghánistán a Irák.

Mezi události významné pro chování NATO patří jeho rozšiřování ve stř̌ední a východní Evropě, jež stále pokračuje. V souvislosti s ním dochází k zhoršování vztahu NATO a především USA s Ruskem, jehož představitelé to považují za snahu zúžit prostor ruského vlivu v místech, jež považují za pásmo své tradiční převahy, čemuž se snaží bránit hlavně ve vztazích k evropské části NATO.

Závěr se věnuje možnostem př́ístího působení NATO vevropském a mimoevropském prostoru. $V$ druhém případě se jedná o záležitost vzešlou hlavně z prostř̌edí 90 . let, jež přesahuje do současnosti, a jejich průběh ukazuje, že se NATO takto zachová také v následujících letech, protože jde často o oblasti, kde jeho úkoly vyžadují stěží dopředu stanovitelnou přítomnost.

\section{VZTAHY NATO A USA OD KONCE STUDENÉ VÁLKY DO STŘETU V KOSOVU}

Ze studené války vyšly jak USA, tak NATO jako vítězové. Společenství seskupené kolem SSSR se rozpadlo a stejně tak zanikla velká část moci SSSR samého. Část představitelů zahraniční politiky USA včetně prezidenta George $\mathrm{H}$. W. Bushe však neusilovala o rozvrat SSSR jako státu, protože to chápala jako hrozbu pro mezinárodní bezpečnost. V prvé řadě šlo o prostředí v neruských částech SSSR. ${ }^{1}$

Se státy ve střední a východní Evropě patřícími za studené války bud' do prosovětského bloku, nebo přímo do SSSR sice USA a NATO začalo spolupracovat, ale ještě nešlo o vstup do NATO, o který projevovali zájem hlavně prezidenti ČSFR, Mad'arska a Polska, což se potvrdilo při jejich setkání v Praze v květnu 1992. ${ }^{2}$ Zařazení se do nejsilnějšího bezpečnostního společenství v Evropě považovali za výhodné zajištění bezpečnosti svých států proti př́lišnému vlivu sjednoceného Německa a Ruska a šíŕení střetů z Jugoslávie do okolí, považovanému začátkem 90. let za nebezpečí, na jehož zvládání by tyto státy samy nestačily. Požadavky na vstup do NATO splnily koncem 90. let, ale už předtím se zúčastnily některých jeho zásahů mimo jeho hranice. Šlo o spolupráci na misích v bývalé Jugoslávii, mezi nimiž si významné místo získala IFOR probíhající v Bosně a Hercegovině.

Rozšiřování NATO během 90. let nepovažovaly všechny politické špičky jeho dosavadních států za přínos. Při vstupu pobaltských států se objevovaly představy, že se tak vyvolá zostření vztahu s Ruskem, což nechtěly. Jednání o rozšiřování začalo až po stažení poslední ruské vojenské přítomnosti z Polska v září 1993 a z Pobaltí v létě 1994. Požadavky některých uchazečů o místo 
v NATO na pomoc z jeho strany se považovaly hlavně v USA za přehnané, zvláště ty, jež vzneslo Rumunsko v průběhu vyjednávání v létě 1997.

Francie usilovala o větší vliv v Evropě, než jaký si zachovávala za studené války. Ve vnitřní politice NATO se to projevovalo prosazováním vstupu států, jež USA v 90. letech nechtěly odsouhlasit, Rumunska a Slovinska. Prezident Francie Jacques Chirac považoval za vhodné, aby se po studené válce stalo uspořádání světové politiky prostředím s více mocenskými póly a Evropou pod zvýšeným vlivem Francie jako protiváhou k moci USA. S těmito záměry souvisela snaha o rozsáhlejší program evropských ozbrojených sil mimo NATO, jež zahraniční politika Francie často chápala jako př́liš proamerické.

USA považovaly $v 90$. letech NATO hlavně za společenství významné pro bezpečnost v Evropě a vztah s Evropským společenstvím (ES, po r. 1992 EU). Zvláštní geopolitickou pozornost zaměřovala jejich diplomacie na Německo a Rusko. USA usilovaly po sjednocení Německa o jeho setrvání v NATO, což chápaly jako ochranu proti německým představám o posunu k jednostrannému prosazování své moci. Americká politika se věnovala také možnosti německé hrozby, kdyby Německo získalo jaderné zbraně.

Většina německých politických špiček tak rozsáhlé představy o vlivu Německa v zahraničí nezastávala a stejně tak se chovala většina německé veřejnosti sledující v prvé řadě vnitropolitické záležitosti spojené se sjednocením, hospodářstvím a přistěhovalectvím. V prvé polovině 90 . let se většinou stavěla proti účasti armády v zahraničních misích, souhlasila však s účastí na řešeních střetů ,uhlazenou“ mocí. ${ }^{3}$

V polovině 90. let se NATO a hlavně USA snažily o širší spolupráci s Ruskem pomocí Partnerství pro mír, založeného v Bruselu v lednu 1994. Zaměřovalo se na státy Severoatlantické rady (NACC) a Konference o bezpečnosti a spolupráci v Evropě (KBSE). Clinton při setkání s prezidentem Ruska Borisem Jelcinem v Helsinkách v březnu 1997 souhlasil s jeho požadavkem, aby se síly NATO nepohybovaly kolem ruské hranice. Spojenectví NATO a Ruska potvrdila jednání v Paříži v květnu 1997. Na tehdejších vztazích USA a Ruska se projevilo, že jejich prezidenti spolu vycházeli i osobně.

NATO se shodlo na zajištění bezpečnosti v prostoru bývalé Varšavské smlouvy a na obraně proti menším střetům v Evropě a okolí, teroristickým skupinám a šíření zbraní hromadného ničení do rukou těch, kdo by zpochybňovali stávající uspořádání moci. Z nenásilných hrozeb se mezi úkoly NATO dostaly přírodní pohromy. ${ }^{4}$

Terorismus jako hrozba nevyvolával takový ohlas jako po 11. záŕí 2001. V Evropě se od poloviny 70. let dodnes odehrálo více teroristických útoků než v USA. Většinou šlo o místní teroristy. Boj proti nim se, až na výjimky jako protibritské útoky severoirských teroristů, chápal jako úkol policie prŕíslušného státu, v případě mezinárodního terorismu pro vícestrannou a spíše př́ležitostnou spolupráci policií zúčastněných států. Proti USA útočili mezinárodní teroristé především v období mezi r. 1971-1974, 1983-1986, 1989-1992 a 2001. Růst představ o tomto ohrožení způsobily v USA útoky proti Světovému obchodnímu středisku v New Yorku r. 1993 a federálním úřadům v Oklahoma City r. 1995. USA proti nim zasahovaly samy nebo s jinými spojenci než s NATO, jehož vliv sem nesahal.

Státy NATO se v prvé polovině 90 . let zúčastnily několika střetů mimo Evropu, ale nestalo se tak v rámci NATO, ale na základě usnesení Rady bezpečnosti OSN anebo pověření od OSN pro mírové mise. Tak se odehrávala válka v Perském zálivu r. 1991 a mise v Chorvatsku, Bosně a Hercegovině a Somálsku mezi r. 1992-1995.

Zvláště válka v Perském zálivu se stala pro státy NATO významnou záležitostí, ostatně všechny poslaly protiiráckému spojenectví pomoc. Vlastního zásahu se kromě USA z NATO zúčastnila hlavně Francie, Kanada a Velká Británie. Většina jeho účastníků pocházela z okruhu středovýchodních států, které v úsilí iráckého prezidenta Saddáma Husajna prosadit Irák jako regionálního (přinejmenším v oblasti Arabského poloostrova a Perského zálivu) hegemona, z něhož vycházelo předchozí dobytí Kuvajtu, viděly nebezpečí. Ropa Kuvajtu by jeho moc zesílila ve vztazích s ostatním světem. 
USA šlo hlavně o ochranu spojenců, zvláště Saúdské Arábie, významného zdroje ropy pro jejich hospodářství. Irácká snaha získat jaderné zbraně a předchozí nasazení chemických zbraní proti kurdskému odboji na severu Iráku r. 1988 vysílaly varování, že podobný vývoj by mohl nastat i tentokrát.

I když se nesplnil předpoklad části architektů zahraniční politiky USA včetně prezidenta Bushe, že se po prohře z r. 1991 Husajnova moc zhroutí, střet znamenal pro USA a zčásti i NATO úspěch, jakého podruhé nedosáhly. NATO se rozhodlo shodně, proti Iráku se vymezila Rada bezpečnosti OSN (rezoluce č. 660. /1990, 661. /1990 a 678. /1991) a většina veřejnosti ve státech NATO, hlavně v USA, se nestavěla proti válce, což souviselo s její rychlostí, malými ztrátami a vlivem sdělovacích prostředků popisujících Irák jako jejího viníka. Představitelé zahraniční politiky USA, jež s ní nesouhlasili, nedokázali své názory prosadit.

Účast muslimských států, zvláště iráckých sousedů, na protiirácké straně znamenala pro vítěze ideologicky významnou pomoc, která za druhé války proti Iráku z jara 2003 scházela. ${ }^{5}$ Ukázala, že se státy odlišné polohou, politickým a náboženským prostředím dokázaly sjednotit, i skutečnost, že jde o př́ležitostné spojenectví.

Zlom ve vývoji NATO v 90. letech představují mise v bývalé Jugoslávii. Od začátku jejího rozpadu provázeného střety mezi znepřátelenými nacionalisty se chování států NATO vyznačovalo neshodami. USA po dobu Bushova prezidentství chtěly zůstat nezúčastněné. Rozhodující vliv

v jejich diplomacii zastávali často konzervativci, kteří nepovažovali Balkán za tak vlivnou oblast, aby v ní ozbrojené síly USA zasahovaly. Za důležitější chápali území na Středním východě, hlavně Saúdskou Arábii a Izrael, v Evropě vztah k NATO a Rusku. ${ }^{6}$ Rozvrat Jugoslávie, stejně tak jako SSSR, nechtěli a chápali ho jako cestu $\mathrm{k}$ střetům, jež na národně a nábožensky smíšených územích po rozvratu ústřední moci hrozily.

Část amerických i evropských politiků zastávala představu, že se větší předpoklady pro šíření bezpečnostních hrozeb nacházejí spíše než na Balkáně v Africkém rohu (Somálsko), v Karibském moři (Haiti) a jižní Asii (Pákistán). Tato místa se vyznačovala zvraty následujícími po konci autoritářské vlády. Jugoslávie koncem 80. let ve srovnání s nimi působila jako nedemokratický, ale uspořádaný stát.

Nasazení armády USA v mírových misích OSN v Somálsku (UNOSOM I. a později UNOSOM II.) r. 1992 a 1993-1994 neuspělo. UNOSOM I. dostala pověření zajistit pomoc obyvatelům poškozeným rozvratem státu a střetem znepřátelených místních diktátorů a pro dohled na příměří z března 1992. UNOSOM II. náležel úkol poválečné obnovy, pomoc v politických a správních změnách, dozor na bezpečnost a odzbrojení porušitelů příměří. USA se rozhodly pro účast také v misi UNITAF, schválené OSN, ale řízené př́ležitostným spojenectvím, v němž si zachovaly hlavní vliv. Šlo o pomoc pro UNOSOM I., jež své poslání nezvládala. Zkušenosti ze Somálska rozumělo mnoho diplomatů a armádních velitelů v USA tak, že tento druh zahraniční politiky USA poškozuje.

Bill Clinton z Demokratické strany, od r. 1992 prezident USA, vstoupil do Bílého domu s kritikou svého republikánského předchůdce, že se př́liš věnoval zahraničí na úkor vnitřních záležitostí USA. Zahraniční politika USA se musí, jak tvrdil, řídit zásadami uznávanými za základ jejich vnitřní politiky. Chtěl snížit rozsah armády, jenž považoval za přehnaný, a v zahraniční politice spoléhat především na diplomacii. Jako prvý z amerických prezidentů od Franklina D. Roosevelta nesloužil v armádě, což mohlo zhoršit vztah veřejnosti $\mathrm{k}$ jeho schvalování účasti jejích zahraničních misí.

Ze států NATO do vývoje v bývalé Jugoslávii zasáhlo mezi prvními Německo, když uznalo nezávislost Slovinska a Chorvatska. ES - EU se k jejich uznání rozhodlo v lednu 1992. Velká Británie s tím nesouhlasila, ale otevřeně se proti nestavěla. S bosensko-hercegovskou a makedonskou samostatností souhlasilo ES - EU v dubnu 1992 a dubnu 1993. Úsilí ES o zachování Jugoslávie v hranicích z r. 1990, jež vedlo v srpnu 1991 k jednání v Haagu za předsednictví lorda Petera Carringtona o ukončení zdejších střetů, se vlivem neshod mezi jeho 
nejvýznamnějšími zástupci ukázalo jako neprůchodné. Nejednota ve vztahu k vývoji v bývalé Jugoslávii převládla i v NATO, včetně politiky jeho nejvlivnějších států.

V německém vztahu k Slovinsku a ještě více Chorvatsku sehrálo úlohu, že se mezi tvůrci jeho zahraniční politiky nacházeli zástupci Křest’ansko-demokratické strany (unie, CDU-CSU) a že se většina Slovinců a Chorvatů hlásí k římskokatolickému vyznání, tvořícímu část jejich národního vymezení. V jejich úsilí o nezávislost hledali nové spojence a větší vliv v Evropě.

USA uznaly Bosnu a Hercegovinu, Chorvatsko a Slovinsko také v dubnu 1992. ES - EU a USA se rozhodly zohlednit převažující přesvědčení mezi obyvateli jmenovaných území, kteří většinou chtěli odtržení od Jugoslávie. ES - EU žádala na nových státech povolení samosprávy menšin a jejich právní ochranu. S výjimkou Slovinska se vztahy zdejších národů často odehrávaly přes souhlas s požadavkem ve znamení střetů, největších v Evropě po II. světové válce. ${ }^{7}$

S touto zahraniční pomocí vstoupily v květnu 1992 Bosna a Hercegovina, Chorvatsko a Slovinsko do OSN. Nová Jugoslávie, skládající se z Srbska (včetně Kosova a Vojvodiny) a Černé Hory musela na vstup do OSN čekat a kromě toho se na ni od června 1991 vztahovalo embargo od OSN, což zasáhlo její hospodářství.

K působení NATO v bývalé Jugoslávii došlo v únoru 1994 v souvislosti s bosenskohercegovskou válkou. Mezi jeho politickými špičkami převážil názor, že je zapotřebí vyvarovat se pozemního tažení, protože by z toho mohly vzejít ztráty. Už beztoho malá vstřícnost veřejnosti zúčastněných států k nasazení armády na úkoly nesouvisící s zajištěním obrany vlastního státu by pak klesla. ${ }^{8}$ NATO se předtím chovalo jako společenství na obranu jeho států a střety v Bosně a Hercegovině žádný neohrožovaly. Rozhodnutí pro misi odlišné povahy znamenalo něco nevyzkoušeného a většinou se pokládalo za potřebné získat souhlas Rady bezpečnosti OSN pro mise prosazující mír (peacebuilding) nebo dohlížející na jeho zachování (peacekeeping), k druhé možnosti scházela dohoda znepř́átelených stran o konci války. ${ }^{9}$

Po ostřelování Sarajeva bosensko-srbskou armádou vyhlásilo NATO pásmo v rozsahu 8 mil okolo Sarajeva jako oblast se zákazem přítomnosti těžkých zbraní, hlavně děl a tanků. Následovalo porušování tohoto pravidla, NATO odpovědělo nálety na bosensko-srbské cíle, což muselo po zajmutí zástupců mise OSN (UNPROFOR), většinou Francouzů a Kanad'anů, bosenskými Srby ukončit. Francie a Kanada je nechtěly jejich pokračováním ohrozit, a proto ho zablokovaly.

V červenci 1995 se holandská jednotka UNPROFOR ve Srebrenici dostala do bosensko-srbského zajetí, což vyvolalo neshody v NATO, jak se zachovat. USA a Velká Británie nechtěly začít s pozemním útokem proti bosenským Srbům, Francie ale o jeho vedení usilovala. Mezi prezidenty Francie a USA vládlo přesvědčení, že NATO musí zasáhnout, ale nedokázali se shodnout na povaze nasazení. Francouzský prezident Chirac jednotě NATO nepomohl, když obvinil většinu jeho zástupců a OSN z neschopnosti (velení UNPROFOR ale řídil Francouz, gen. Bernard Janvier) zvládat vzešlé nesnáze. ${ }^{10}$ Francie se pro samostatný zásah nerozhodla, což posilovalo představu o přehnaném Chiracově sebevědomí, po jehož projevech nenásleduje hmatatelný úspěch.

Zajetí představitelů UNPROFOR posílilo kritiku OSN a států zajišt'ujících UNPROFOR, která tvrdila, že mise mír v Bosně a Hercegovině neprosadí, protože jí k tomu schází technické i politické síly, což vychází z rozsahu pověření OSN pro její působnost. Ta se soustřed'ovala na ochranu oblastí, jež OSN označila za „,chráněné zóny“. V Bosně a Hercegovině zahrnovaly Bihač, Goražde, Sarajevo, Srebrenici, Tuzlu a Žepu.

Propuštění zajatých vojáků UNPROFOR se dosáhlo až po nátlaku srbského prezidenta Slobodana Miloševiće na bosenské Srby, potvrzujícím jeho vliv a omezený rozsah moci EU a NATO v bývalé Jugoslávii.

Nová vlna náletů NATO proti bosenským Srbům od srpna do záŕí 1995 neusilovala pouze o ukončení jejich střelby na Sarajevo, ale hlavně o jejich souhlas s jednáním o míru, k jehož uzavření došlo v Daytonu v prosinci 1995. Většina amerických a evropských politiků se shodovala na tom, že bez rozdělení Bosny a Hercegoviny nelze mír zachovat. Úsilí části z nich o zachování jejího mnohonárodního složení v unitárním státu vlivem předchozí války neuspělo. Někteří, hlavně 
zvláštní pověřenec USA pro Balkán Richard Holbrooke, považovali bosensko-srbské politiky za darebáky ovlivnitelné jen nátlakem. ${ }^{11}$

Po zhoršení Clintonovy podpory v Kongresu, kde v průběhu r. 1995 získali převahu republikáni usilující o neúčast USA na bosensko-hercegovských misích NATO, se americký prezident musel $\mathrm{v}$ prosazování svých zahraničních záměrů více spoléhat na pomoc z OSN a NATO. ${ }^{12}$ Veřejnost v USA stála převážně na straně Clintonových kritiků. Hlavní úlohu v jejích názorech hrály náklady na tuto část zahraniční politiky a její nepř́liš výrazný úspěch.

Američtí kritici Clintonovy balkánské politiky tvrdili, že se nechala ovlivnit liberálními sdělovacími prostředky, představujícími se jako šiřitelé ochrany lidských práv ve světě. Tato ochrana se podle nich odehrávala i na úkor národních zájmů USA. V působení NATO v Bosně a Hercegovině hledali v prvé řadě snahu jeho evropských států o vzestup vlivu. Tito spojenci USA málo pomáhají, i když právě ony hradí většinu výdajů NATO.

Takto popisovali chování Francie za americko-britského nátlaku pomocí náletů na Irák z r. 1996 a 1997 usilujícího o souhlas se vstupem mezinárodní kontroly dohlížející na zničení jeho zásob zbraní hromadného ničení, čemuž bránil.

Rezoluce Rady bezpečnosti OSN č. 1031 z r. 1995 znamenala právní základ mise IFOR v Bosně zajištěné NATO od konce tohoto roku do r. 1996. Na ni navazovala mise SFOR trvající mezi r. 1996-1998, která se soustřed'ovala na dozor na zachování míru (peacekeeping), zatýkání podezřelých z válečných zločinů a program odstranění škod z předchozích stř̌etů, jejichž provoz krylo NATO, přičemž náklady zabezpečovali v nadpoloviční většině evropští zástupci.

SFOR přinesla změnu v nasazeních Bundeswehru mimo Německo, protože pro ně uvolnila bojové jednotky. Od r. 1960, kdy Německo poprvé od II. světové války vyslalo armádu do zahraničí, do r. 1994 zajišt'ovala vždy nebojové úkoly mezinárodních misí. Pro rozšiřrení jejího poslání za tehdejší hranice ústavy (článek č. 87/a.) se rozhodl Ústavní soud r. 1994 a prosazovali ho armádní generální inspektor gen. Klaus Naumann a ministr obrany Volker Rühe (z CDU). Jeho usnesení se stalo základem pro účast Německa v mezinárodních misích bojové povahy.

Část poslání SFOR převzala v prosinci 2004 vojenská mise EU, EUFOR - Althea, výjimkou zůstalo zadržování podezřelých z válečných zločinů, jež dále řídilo NATO.

\section{POSLEDNí ZKOUŠKY SPOLUPRÁCE V NATO: KOSOVO, AFGHÁNISTÁN, IRÁK}

Kosovo považovaly NATO a EU za místo šíření bezpečnostních hrozeb, gangsterství, násilných politických převratů, př́ilivu uprchlíků a teroristů už před vrcholem střetu kosovských Albánců a Srbů z r. 1998-1999. Všechny státy NATO a Rusko se shodovaly, že je ho zapotřebí ukončit, protože hrozil přenos do Černé Hory, západní Makedonie a jižního Srbska.

Zde shoda mezinárodního společenství končila. Rusko se rozhodlo postavit se na srbskou stranu výrazněji než za válek v Chorvatsku a Bosně a Hercegovině a blokovalo v Radě bezpečnosti OSN usnesení postihující Srbsko. Jeho chování navazovalo na vzor jeho carského předchůdce z druhé poloviny 19. století, hledajícího pro spolupráci stát s převážně slovanským pravoslavným obyvatelstvem v oblasti, již považovalo za zónu svého vlivu.

USA a část NATO, které se rozhodly pro protisrbský postup, tak ztratily právní pomoc, jíž využívaly při misích v Bosně a Hercegovině. Nejvyšší představitelé USA a Velké Británie tvrdili, že musí jednat bez souhlasu Rady bezpečnosti. To neznamenalo nic převratného, USA provedly r. 1983 jednostranný zásah proti protiamerickým skupinám v Libanonu a Francie vícekrát nasadila armádu bez širšího mezinárodního spojenectví a souhlasu OSN v Africe ve svých bývalých koloniích.

Vyhraněný odboj proti srbské vládě v Kosovu představovala hlavně Kosovská osvobozenecká armáda (UCK), ta však nezastupovala většinu zdejšího albánského obyvatelstva nebo stát. To se lišilo od spolupráce mezi NATO a bosensko-hercegovskými Muslimy. Mezinárodní právo se i po studené válce vymezuje $\mathrm{k}$ vedení války většinou jako $\mathrm{k}$ záležitosti států. Č́st návrhů na jeho změnu 
právo vést válku vztahuje i na nestátní síly, většinou za předpokladu, že mluví jménem vymezitelného společenství, jež je za své zástupce uznává. Kromě toho se po nich žádá, aby nejprve využily všech nenásilných řešení, a i potom, co střet začal, projevily ochotu k vyjednávání.

Nálety NATO proti Srbsku od března do června 1999 se staly prvním nasazením mimo jeho hranice bez souhlasu OSN. NATO dosáhlo odchodu srbských ozbrojených sil z Kosova a souhlasu OSN se zř́izením mise KFOR (rezoluce Rady bezpečnosti č. 1244/1999) dohlížející na zachování míru, což narušily střety mezi Albánci a Srby, jimž KFOR nedokázala zabránit. KFOR se v Kosovu, hospodářsky vždy nejslabší části bývalé Jugoslávie, starala také o zavádění programů poválečné obnovy. Její poslání zahrnovalo také pomoc při návratu uprchlých a vnitřně vysídlených obyvatel, odzbrojení UCK, ochranu kulturních památek, zabavování nezákonně vlastněných zbraní a zásahy proti jejich pašování. Mise ve většině těchto úkolů, stejně tak jako snahy EU a USA změnit místní politické prostředí, aby více vyhovovalo jejich představám o demokracii, neuspěla.

Mnozí zástupci Republikánské strany v USA útok proti Srbsku kritizovali, protože vliv evropských států v NATO, především Francie, považovali za nevýhodný pro USA. Většina z nich tvrdila, že USA zvládnou zajištění takové mise samy. ${ }^{13}$ Proti zásahu NATO se vymezovali i konzervativní a tradicionalističtí politici jako bývalý ředitel odboru Bílého domu pro jednání se sdělovacími prostředky za prezidentství Ronalda Reagana, Patrick J. Buchanan. Podle nich Srbsko USA neohrožovalo, a útok tak postrádal smysl.

Ve Velké Británii nesouhlasili s nálety někteří představitelé předchozích vlád z konzervativní strany jako sir Malcolm Rifkind a baron Norman S. H. Lamont a levicovější část labouristů, zvláště poslanci Tony Benn a Alan J. Simpson. V žádném z nejsilnějších států NATO nesouhlas s chováním k Srbsku nezměnil jeho balkánskou politiku.

NATO zprvu neusilovalo pomoci kosovským Albáncům k získání vlastního státu, ale USA se tak v následujícím desetiletí rozhodly, protože považovaly stav Kosova pod správou NATO a OSN (mise UNMIK) za neúnosný. Jeho nezávislost vyhlášenou v únoru 2008 uznala většina států NATO za několik týdnů, přítomnost KFOR zůstala, protože se vztahy Albánců a Srbů neurovnaly a vládne zde vyhrocenější vztah než mezi Chorvaty, Muslimy a Srby v Bosně a Hercegovině.

Po útocích al-Káidy proti USA z 11. záŕí 2001 v NATO panovaly zřejmě největší neshody od jeho založení. USA nepřijaly návrh NATO na společný postup podle pravidel o obraně, kde se stanovilo, že proti útoku na kteréhokoliv člena společenství zasahuje celé NATO, protože chápaly jako vhodnější sestavení příležitostného spojenectví, jehož skladba vychází z povahy úkolu.

NATO označilo al-Káidu a jejího spojence, afghánské hnutí Tálibán, za nepřátele. Rozdělení začalo spolu s úsilím USA zaútočit v rámci ,války proti terorismu“ na Irák, jenž obvinily z pomoci pachatelům zářijových útoků, snahy získat zbraně hromadného ničení a využít je proti USA a jejich spojencům. Většina veřejnosti v státech NATO mimo USA s útokem na Irák nesouhlasila.

Shoda vlád části států NATO se záměrem USA neznamenala bezvýhradné následování zahraniční politiky USA. Také nesouhlas s válkou v Iráku z jara 2003 nemusel souviset s protiamerickým založením jeho zastánců. Velká Británie, Španělsko a Itálie, nejvlivnější státy z části NATO, jež se postavily na stranu USA, se s nimi neshodovaly v názoru na izraelsko-palestinské vztahy, Kjótský protokol a Mezinárodní soudní tribunál. Část NATO v Evropě a EU považovala vliv Francie a Německa, hlavních zástupců obou společenství nesouhlasících s chováním USA k Iráku, za přehnaný.

Německá zpravodajská služba pomohla USA přes tyto neshody proti protiamerickým islamistům. Německé velvyslanectví v USA založilo fond na pomoc poškozeným útoky z 11. zárí. NATO zastávalo přesvědčení, že je třeba Irák odzbrojit. Francie a Německo, ze států mimo NATO Rusko, tvrdily, že by se toho dosáhlo zbrojní kontrolou, zatímco USA, Španělsko a Velká Británie s tím nesouhlasily a nevěřily úspěšnosti jiných způsobů dosažení změny politiky Iráku než válce, protože podle jejich názoru jeho vládě nebylo možné věřit.

Vývoj v NATO ovlivňoval parlamentní volby v Německu na podzim 2002. Většina voličů účast $\mathrm{v}$ připravované válce $\mathrm{s}$ Irákem nechtěla. Proto spolkový kancléř a šéf sociálních demokratů Gerhard Schröder prohlásil, že by USA ve válce proti Iráku nepomohl, i kdyby získaly souhlas 
OSN. Po vítězství ve volbách se zachoval k USA vstřícněji, což znamenalo povolení k využití německých letišt' a vzdušného prostoru pro dopravu k zásobování armády USA v Iráku. Německo a Francie se nepřipojily k misi NATO na obranu Turecka, jež vycházela z předpokladu útoku Iráku na nejbližší část NATO, i když Německo tvrdilo, že kdyby začal, spojeneckou povinnost by splnilo.

Francie se snažila dosáhnout, aby menší státy NATO, jež víceméně jednaly za války v Iráku ve shodě s USA, Česká republika, Mad'arsko a Polsko, s touto politikou přestaly, ale neuspěla, což jistě ovlivnilo povýšené jednání prezidenta Chiraca.

Za tohoto stavu se konalo setkání zástupců NATO v Praze v listopadu 2002, z kterého vzešel závěr, že NATO končí s vymezením jako obranné společenství států, jehož ozbrojené síly nezasahují za jejich hranicemi. Pozornost se věnovala misím mimo jeho území, především k ISAF v Afghánistánu, s níž souhlasila jeho vláda a Rada bezpečnosti OSN. Pro krytí potřeby boje proti teroristům a krátké mise založilo Sbor rychlé reakce (NRF). Toho chtěly dosáhnout zvláště USA, jež ho r. 2002 zařadily mezi součásti své národní bezpečnostní strategie.

NATO se shodlo na jednání o prŕístupu Bulharska, Estonska, Litvy, Lotyšska, Rumunska, Slovenska a Slovinska do svých řad a na zvýšení bezpečnostní spolupráce s EU.

NATO souhlasilo s rezolucí Rady bezpečnosti OSN č. 1441/2002 vyzývající Irák k povolení vstupu zbrojních kontrolorů na jeho území a uznání pravidel ze starších rezolucí, zvláště z období 1990-1991, zakazujících mu vlastnit zbraně hromadného ničení a některé další zbraně. Zavázalo se pomoci OSN změnit irácké chování a souhlasilo s blíže nevymezenou hrozbou Iráku, když změna nenastane.

Vstupu ISAF do Afghánistánu předcházel od října 2001 do ledna 2002 útok USA, Velké Británie a jejich zdejších spojencủ, převážně Spojené islámské fronty spásy Afghánistánu, označované také jako Severní spojenectví, proti Tálibánu a al-Káidě. Jeho pokračování v březnu 2002 se z NATO účastnily i Kanada, Německo a Norsko. Předcházel mu spor, zda ho lze označit za společnou obranu podle Charty OSN, čl. 51, jak to tvrdili jeho prríznivci. Část právního podkladu zajistily rezoluce Rady bezpečnosti OSN č. 1368 a 1373 proti terorismu z r. 2001.

Poslání ISAF zprvu shrnovala rezoluce Rady bezpečnosti OSN č. 1386 z prosince 2001, jež její pravomoc omezovala na Kábul. Její rozššření do dalších částí Afghánistánu zajistila rezoluce

č. 1510 z října 2003. Většina jejích prvních sil pocházela z evropských států NATO, hradících přes polovinu jejích nákladů. Schválení neprovázely větší neshody. ISAF působí při výstavbě afghánské armády, poválečné obnově a dohledu na zachování míru. Poslední úkol představuje bojovou misi, protože Tálibán přechází v posledních měsících do protiútoku a zřejmě využívá pohraniční oblasti Pákistánu, zvláště Severozápadní pohraniční provincii (NWFP) jako úkryt. Zásahy ISAF

v Pákistánu poškozují postavení jeho vlády, spojence USA proti Tálibánu a al-Káidě. Pákistánští islamisté to využívají pro širrení vlivu, protože politiku USA většina Pákistánců označuje za protipákistánskou.

Afghánská armáda sama proti Tálibánu nestačí, zvláště ne na jihu a v části středního Afghánistánu. Tálibán získal ovládnutím území s rozsáhlou výrobou drog více peněz. USA potřebují posily NATO pro ISAF, aby mohly uvolnit část svých jednotek z Afghánistánu pro Irák, jehož bezpečnost nedokázaly od války v březnu 2003 zajistit. Za vhodného spojence považují Francii, jejíž prezident Nicolas Sarkozy se snaží o větší spolupráci s USA než Chirac, a Německo. Většina obyvatel států NATO se zvýšením nasazení svých armád v Afghánistánu nesouhlasí. Často pro ně ISAF znamená proamerickou, ale jim samým nic nepřinášející a drahou misi, a proto usilují o její konec do závěru současného vymezení stanoveného na r. 2009. Rozšíření účasti Bundeswehru v ISAF v lednu a únoru 2007 o leteckou dopravu se setkalo s kritikou, že ISAF mluví o úspěších, většinu území Afghánistánu však neovládá, jestli to vůbec lze, a že se Německo zapojilo do mnoha mezinárodních misí, jež nezvládá.

Velitelé americké a britské armády kritizují hlavně Francii a Německo za neochotu poslat ISAF více bojových sil, což zhoršuje vztah jejich podřízených, spolu s Holand'any a Kanad'any zastávajícími nejnebezpečnější úkoly, k Francouzům a Němcům. Často tvrdí, že ISAF musí po 
r. 2009 pokračovat, jinak své poslání nezvládne. Předseda britské vlády Tony Blair se o změnu chování spojenců neúspěšně snažil na jednání v Bruselu v březnu 2007.

Války v Iráku se NATO nezúčastnilo, v současnosti jeho tamní mise (NTM - I.) zajištuje výcvik armády a policie. O pomoc NATO pro Irák žádal předseda jeho prozatímní vlády Iyad Allawi v červnu 2004. NTM - I. začala v červenci 2004. Ve srovnání s ISAF i KFOR jde o menší nasazení. Irácký předseda vlády Nuri al-Maliki žádal o její prodloužení do r. 2009, protože výstavbu ozbrojených sil nepovažoval za hotovou. Bezpečnost v Iráku ohrožují vnitřní střety a útoky islamistických skupin přišedších bojovat proti USA ze zahraničí a pobyt NTM - I. se zřejmě prodlouží. ISAF a NTM - I. přesunuly hlavní pozornost NATO na Střední východ.

NATO vysílá mise i do vzdálenějších oblastí. R. 2005 připravovalo pomoc pro část USA zasaženou hurikánem „Katrina“, podobně pomáhalo v Pákistánu postiženém zemětřesením. V souvislosti s dopravou sil pro zásah Africké unie (AU) za spolupráce s OSN v Darfuru (UNAMID) jednala r. 2005 AU s NATO o jejím zajištění a NATO od června 2005 do prosince 2007 řídilo př́lety UNAMID.

Setkání zástupců NATO v dubnu 2008 v Bukurešti se věnovalo postavení ISAF a významu Pákistánu pro afghánskou bezpečnost. NATO se shodlo, že spojenectví s Pákistánem je zapotřebí rozširirit. Mezi místní spojence náleží mise OSN (UNAMA). Jednání NATO se soustředila také na Irán. NATO se postavilo proti jeho jadernému programu a souhlasilo s rezolucemi Rady bezpečnosti OSN č. 1696/2006, 1737/2006, 1747/2007 a 1803/2008 proti rozšiřování jaderných zbraní. Došlo k jeho dohodě na nesouhlasu s jaderným programem Severní Koreje, přičemž chce, aby ho, v souladu s rezolucí Rady bezpečnosti OSN č. 1718/2007, ukončila.

Záměr USA vystavět v Evropě radarová a raketová zařízení často označují jeho příznivci za ochranu proti možné hrozbě útoku z Iránu nebo Severní Koreje. NATO se, jako odpověd' na tento projekt, snažilo o rozšíření spolupráce s Ruskem a USA. Vyzvedlo ruskou spolupráci s ISAF, když povolilo přepravu pomoci pro tuto misi přes své území. Souhlasilo s potřebností řešit střety v Arménii, Ázerbajdžánu, Gruzii a Moldávii nenásilně a bez porušení svrchovanosti. Gruzie a Ukrajina rozšíríly spolupráci s NATO s cílem vstupu do tohoto společenství, s nímž však část států NATO, zvláště Francie a Německo, nesouhlasí, protože oba státy nepovažují za zcela připravené na tuto změnu a nechtějí zhoršit vztah s Ruskem.

Názor USA na rozšîrrení NATO vychází z Národní bezpečnostní strategie z r. 2006, jež jako jeho předpoklad uvádí splnění požadavků NATO zájemci o vstup. Proti možnosti jeho růstu o další státy se tedy nestaví. Bukurešt'ská jednání se stala základem pro otevření prrijímacího programu NATO pro Albánii a Chorvatsko; Makedonie se do něj i přes svou snahu nedostala. Úlohu sehrál řecký nesouhlas. NATO schválilo trvání KFOR, protože bezpečnost v Kosovu se nezlepšila tak, aby mise mohla skončit. Jiné stanovení konce KFOR by NATO uznalo, kdyby tak rozhodla Rada bezpečnosti OSN. NATO požaduje po Bosně a Hercegovině a Srbsku pokračování spolupráce s Mezinárodním trestním tribunálem stíhajícím zločiny spáchané za válek v bývalé Jugoslávii.

\section{ZÁVĚR}

NATO prošlo po skončení studené války vývojem od obranného společenství k seskupení působícímu i při dohledu na zachovávání míru a jeho tvorbě, pomoci na obnově vúzemích zasažených násilím a $\mathrm{v}$ boji proti teroristům. Několik těchto misí trvalo více let. $\mathrm{V}$ Bosně a Hercegovině pomohly k míru, ale představy části amerických a evropských politických špiček o její jednotné a zároveň mnohonárodní podobě, nešlo prosadit bez chybějící spolupráce se zástupci místní politiky. KFOR, nejstarší současná mise, své poslání zvládla jen zčásti, protože nedokázala ukončit stř̌ety kosovských Albánců a Srbů.

Zřízením a zesílením ISAF ubyly prostředky pro ostatní mise NATO, což ovlivňuje jejich úspěšnost. ISAF zůstává pro NATO nejvýznamnějším nasazením a její selhání by ho podle nejkritičtějších scénářů mohlo rozvrátit. Průběh ISAF ztěžuje, že ji nelze skončit rychle. 
USA se na spojenectví v NATO spoléhaly více než na spolupráci s EU. I přes neshody se NATO vyznačuje větší snahou o shodu v bezpečnostní politice i zahraničních vztazích než EU. K zániku NATO po sporech po 11. září 2001 nedošlo. Rozdělení na státy spolupracující ve větším rozsahu s USA a ostatní neznamenalo, že by zástupci těchto skupin přestali spolupracovat.

Část Američanů chápe NATO jako seskupení, jež vliv USA omezuje, protože jim málo pomáhá, zato však s jejich rozhodováním mnohdy nesouhlasí. Evropská kritika amerického vlivu v NATO často není zajedno s vojenským velením v rukou USA. NATO pro USA ani evropské státy nepředstavuje nejlepší spojenectví, ale žádná z obou stran nezvládne vést úspěšnou zahraniční politiku sama. NATO tak znamená částečnou výhodu pro obě. Po zlepšení vztahů v NATO by se snáze dosáhlo změn uspořádání světové politiky směrem k vícepólové podobě. USA se po studené válce staly nejsilnějším státem, ale to nestačilo na přechod $\mathrm{k}$ hegemonii, jež chtěla část architektů jejich zahraniční politiky.

Lepší spolupráce USA a ostatních států NATO vyžaduje oboustranné změny chování. USA se po 11. září snažily prosazovat vliv v zahraničí tak jednostranně, že to část jejich spojenců od širší spolupráce s nimi odradilo. Francie se v NATO nesnažila o snížení jejich vlivu poprvé. Bosensko-hercegovská válka prokázala, že na úlohu hegemona jí scházejí prostředky ještě více než USA. Po 11. září našla sice pro politiku k USA spojence v Německu a několika evropských státech, ale to na vyvažování americké moci nestačilo, protože Německo a další státy vyhraněnější rovinu odvracení se od předchozího vztahu k USA opustily.

USA by pomohlo získat silnější postavení, kdyby se více ohlížely na zájmy ostatních států v NATO. Ani NATO však k sestavení spojenectví pro úspěch v světové politice samo nestačí. Pro takový záměr potřebují USA získat pomoc $\mathrm{v}$ jiných částech světa, především v Asii, protože se tu nacházejí vlivní účastníci mezinárodních vztahů jako Čína, Indie a Japonsko, z tradičních amerických spojenců Austrálie, a v Latinské Americe. Pro okolí států seskupených v NATO však toto společenství stále znamená vlivného účastníka tamní bezpečnostní politiky.

\section{POZNÁMKY}

\footnotetext{
${ }^{1}$ BRZEZINSKI, Zbigniew. Second Chance. Three Presidents and the Crisis of American Superpower, s. 6061.

${ }^{2}$ ASMUS, Ronald D. Opening NATO's Door. How the Alliance Remade Itself for a New Era, s. 17.

${ }^{3}$ ASMUS, Ronald D. Germany's Geopolitical Maturation. Public Opinion and Security Policy, s. 41.

${ }^{4}$ SERFATY, Simon. Stay the Course. European Unity and Atlantic Solidarity, s. 5.

${ }^{5}$ DAALDER, Ivo, GOLDGEIER, James. Global NATO, s. 113.

${ }^{6}$ BARNETT, Thomas P. M. The Pentagon's New Map. War and Peace in the Twenty-First Century, s. 120.

${ }^{7}$ Von HIPPEL, Karin. Democracy by Force. U. S. Military Interventions in the Post-Cold War World, s. 131132.

${ }^{8}$ COOPER, Robert. The Breaking of Nations. Order and Chaos in the Twenty-First Century, s. 158.

${ }^{9}$ ZŮNA, Jaromír. NATO. Operace na podporu míru, s. 28-33.

${ }^{10}$ ROHDE, David. A Safe Area. Srebrenica: Europe's Worst Massacre Since the Second World War, s. 255, 302.

${ }^{11}$ MANDELBAUM, Michael. The Case for Goliath. How America Acts As The World's Government in the $21^{\text {st }}$ Century, s. 66.

${ }^{12}$ ALLIN, Dana H. NATO's Balkan Interventions, s. 38.

${ }^{13}$ Van HAM, Peter, KUGLER, Richard L. Western Unity and the Transatlantic Security Challenge, s. 10. ZLATOHLÁVEK, Petr. NATO Response Force. Síly rychlé reakce NATO: úvod do problematiky, s. 70.
} 


\section{LITERATURA}

[1] ALLIN, Dana H. NATO's Balkan Interventions. Adelphi Paper 347. International Institute for Strategic Studies. London 2002. 112 s. ISBN 0-19-85-16-76-2.

[2] The Atlantic Alliance under Stress. U. S. - European Relations after Iraq. Editor Andrews, David M. Cambridge: Cambridge University Press, 2005. 293 s. ISBN 0-521-84927-6

[3] ASMUS, Ronald D. Germany's Geopolitical Maturation. Public Opinion and Security Policy in 1994. Santa Monica: RAND, 1995. 51 s. ISBN 0-8330-2296-2.

[4] ASMUS, Ronald D. Opening NATO's Door. How the Alliance Remade Itself for a New Era. New York: Columbia University Press, 2002. 372 s. ISBN 0-231-12776-6.

[5] BARNETT, Thomas P. M. The Pentagon's New Map. War and Peace in the Twenty - First Century. New York: Penguin Books, 2005. 435 s. ISBN 0-425-20239-9.

[6] BOOT, Max. The Savage Wars of Peace. Small Wars and the Rise of American Power. New York: Basic Books, 2003. 428 s. ISBN 0-465-00720-1.

[7] BRZEZINSKI, Zbigniew K. Second Chance. Three Presidents and the Crisis of American Superpower. New York: Basic Books, 2007. 234 s. ISBN 978-0-465-00252-8.

[8] NATO Enlargement. Illusions and Reality. Editors Carpenter, Ted Galen. Contry, Barbara. Washington, DC: Cato Institute, 1998. 283 s. ISBN 1-882577-59-0.

[9] COOPER, Robert. The Breaking of Nations. Order and Chaos in the Twenty - First Century. London: Atlantic Books, 2003. 180 s. ISBN 0-8021-4164-1.

[10] ENDERS, Walter, SANDLER, Todd. The Political Economy of Terrorism. Cambridge: Cambridge University Press, 2006. 278 s. ISBN 0-521-61650-6.

[11] Van HAM, Peter. KUGLER, Richard L. Western Unity and the Transatlantic Security Challenge. The Marshall Center Papers, No. 4. Garmisch - Partenkirchen: George C. Marshall Center, 2002. 54 s. ISBN 1-930831-06-4.

[12] Von HIPPEL, Karin. Democracy by Force. U. S. Military Interventions in the Post - Cold War World. Cambridge University Press. Cambridge 2001. 224 s. ISBN 0-521-65955-8.

[13] HOFFMANN, Stanley, BOZO, Frederic. Gulliver Unbound. America's Temptation and the War in Iraq. New York: Rowman \& Littlefield Publishers, Inc, 2004. 153 s. ISBN 0-74253600-9.

[14] JOSSELIN, Daphné. Wallace, William. Non - State Actors in World Politics. Basingstoke: Houndmills, 2001. 294 s. ISBN 0-333-96814-X.

[15] LANSFORD, Tom. All for One: Terrorism, NATO and the United States. Aldershot: Ashgate Publishing, Ltd, 2002. 214 s. ISBN 0-7546-3045-5.

[16] MANDELBAUM, Michael. The Case for Goliath. How America Acts As The World's Government In The $21^{\text {st }}$ Century. New York: Perseus Books / Public Affairs, 2005. 283 s. ISBN 1-58648-360-9.

[17] NATO Handbook. Brussels: NATO Office of Information and Press, 2001. $536 \mathrm{s.}$

[18] Governing Globalization. Power, Authority and Global Governance. Editors Held, David. Mc Grew, Anthony. Cambridge: Polity Press, 2005.

[19] ROHDE, David. A Safe Area. Srebrenica: Europe's Worst Massacre Since the Second World War. Glasgow: Pocket Books, 1997. 440 s. ISBN 0-671-00499-9.

[20] SERFATY, Simon. Stay the Course. European Unity and Atlantic Solidarity. The Washington Papers / 171. CSIS. Westport: Praeger, 1997. 115 s. ISBN 0-275-95933-3.

[21] From Alliance to Coalitions - The Future of Transatlantic Relations. Editor Weidenfeld, Werner. Gütersloh: Verlag Bertelsmann Stiftung, 2006. 349 s. ISBN 3-89204-762-6. 
[22] Bezpečnostní ( ne ) stabilita. Editor Jan Závěšický. Praha: Klub mladých Evropanů, 2005. 144 s. ISBN 80-239-5598-5.

[23] ZLATOHLÁVEK, Petr. NATO Response Force. Síly rychlé reakce NATO: úvod do problematiky. Ostrava: Jagello 2000, 2007. 117 s. ISBN 978-80-239-9386-8.

[24] ZŮNA, Jaromír. NATO. Operace na podporu míru. Brno: Vojenská akademie, 2002. 127 s. ISBN 80-85960-37-0.

\section{Články}

[25] CHOREV, Matan. Wherein the Divide? Terrorism and the Future of Atlanticism. Perceptions - Journal of International Affairs. SAM. Spring 2006. Volume IX., Number 1.

[26] DAALDER, Ivo, GOLDGEIER, James. Global NATO. Foreign Affairs, September / October 2006. Volume 85, No. 5.

[27] ERLANGER, Steven. Albright Sees An Ambitious World Mission For The U. S. New York Times [online]. 1997, June 6 [cit. 2008-09-15]. Dostupný zWWW: <http://www.nytimes.com/archive>.

\section{Internetové zdroje}

[28] Bundesministerium der Verteidigung [online]. [cit. 2008-09-15]. Dostupný z WWW: $<$ http://www.bmvg.de>.

[29] EUFOR - Althea [online]. [cit. 2008-09-15]. Dostupný z WWW: <http://www.euforbih.org>.

[30] The Gallup Organization [online]. [cit. 2008-09-15]. Dostupný zWWW: $<$ http://www.gallup.com>.

[31] The National Security Strategy of the United States of America, September 2002 [online]. The White House, National Security Council, 2002 [cit. 2008-09-15]. Dostupný z WWW: $<$ http://www.whitehouse.gov/nsc/documents>.

[32] The National Security Strategy of the United States of America, March 2006 [online]. The White House, National Security Council, 2006 [cit. 2008-09-15]. Dostupný z WWW: <http://www.whitehouse.gov/nsc/documents>.

[33] NATO [online]. [cit. 2008-09-15]. Dostupný z WWW: 〈http://www.nato.int>.

[34] The United Nations, Department of Peacekeeping [online]. [cit. 2008-09-15]. Dostupný z WWW: <http://www.un.org/Depts/dpko>. 